Bulletin of Pharmaceutical Sciences
Assiut University

\title{
EVALUATION OF POTENTIAL PROTECTIVE EFFECTS OF CURCUMIN VERSUS METFORMIN IN EXPERIMENTALLY-INDUCED METABOLIC SYNDROME IN RATS
}

\author{
Abdel-Halim M. Afifi, Hussein I. El-Bitar and Marwa A. Ahmed* \\ Department of Pharmacology, Faculty of Medicine, Assiut University, Assiut 71526, Egypt
}

\begin{abstract}
Metabolic syndrome (MetSyn) is the clustering of various interrelated risk factors of metabolic origin that increased incidence of cardiovascular diseases and type 2 diabetes. In this study the effectiveness of curcumin was evaluated in comparison with metformin in fructose-induced MetSyn disease in rats. Fructose was fed (10\% solution in drinking water) for 8 weeks during which groups of rats were administered once daily vehicle (2\% carboxy methyl cellulose), curcumin (40 and $80 \mathrm{mg} / \mathrm{kg}$ ), metformin (100 and $200 \mathrm{mg} / \mathrm{kg}$ ), their combinations and compared with group received tap water instead of fructose. The results revealed that induction of MetSyn was associated with glucose intolerance, insulin resistance alongside with increased weights of body and visceral fats. This was accompanied with an elevation of arterial blood pressure. Meanwhile, it caused disturbances in lipid profile (triglyceride, total cholesterol, $H D L-C$ and $L D L-C$ ) and both oxidative stress (malondialdehyde, 8-iso-PGF $F_{2 \alpha}$ and superoxide dismutase) and inflammatory status (tumor necrosis factor- $\alpha$, interleukin- $6, C$ reactive protein and adiponectin) parameters. Each of curcumin and metformin significantly prevents, to variable extents, the progression of most of these signs of MetSyn. Furthermore, the efficacy of each of the two drugs in question was significantly augmented upon their concurrent administration. These protective effects of the two drugs under investigation presumably may be relevant to their ability to reduce the oxidative stress and to ameliorate the inflammatory processes.
\end{abstract}

\section{INTRODUCTION}

The metabolic syndrome (MetSyn) is a socially important issue which has drawn attention of many physicians and researchers as its prevalence is gradually escalating around the world. This syndrome includes central obesity, insulin resistance (IR), impaired glucose tolerance (IGT), dyslipidemia and hypertension; associated abnormalities include inflammation and endothelial dysfunction. These risk factors are substantially increase morbidity of cardiovascular diseases and type 2 diabetes $^{1}$. The multiplicity of mechanisms underlying the etiology of these risk factors has necessitated the combined therapy of different drug groups to improve management of MetSyn. However, the non specificity of these used drugs and the possibility of adverse interactions during their coadministration may limit its use ${ }^{2}$. Metabolic syndrome is still not fairly curable and neither prevention strategies nor long treatment modalities are encouraging.

Curcumin, the bioactive phenolic component of spice turmeric has been recently reported to exert surprisingly multipharmacological activities including antiobesity, antidiabetic, cardioprotective, antioxidant, anti-inflammatory, antiproliferative and anticarcinogenesis with no side effects $^{3}$. On this basis, in the past five years, curcumin has rapidly emerged as natural therapeutic to be of potential favourable effects on virtually most components of MetSyn. Indeed, data are scanty and contradictory ${ }^{4}$.

The present study was conducted to give on insight about the possible protective effectiveness of curcumin in comparison with

Received in 7/7/2014 \& Accepted in 29/9/2014 
metformin, which is widely used in the treatment of MetSyn, in fructose-fed rats (FFR). The effects of chronic oral administration (8 weeks) of two dose levels of these two drugs either solely or in combinations on the lipid profile, body and visceral fat weights, obesity, glucose tolerance and IR-index were investigated. Moreover, the effects on both oxidative stress and inflammatory status together with arterial blood pressure (ABP) were assessed. To our knowledge the interrelation-ship between the effects of curcumin and/or metformin and these parameters has not been evaluated simultaneously thus far.

\section{MATERIALS AND METHODS}

\section{Animals and induction of metabolic syndrome}

Adult male albino-Wistar rats (180-200 gm) were obtained from the animal house of Faculty of Medicine, Assiut University. Rats were housed under standard laboratory conditions and supplied with laboratory chow and tap water ad libitum. All rats were randomly assigned to 8 groups each comprised 14-16 animal. All the procedures were approved by the Animal Care and Use Committee of the Faculty of Medicine, Assiut University.

For the induction of MetSyn in rats, the fructose model described by Dai and $\mathrm{McNe} \mathrm{Nl}^{5}$ was followed. In this method, fructose solution $(10 \%)$ was freshly prepared every two days. This solution was used for drinking the rats instead of tap water for 8 consecutive weeks.

\section{Drugs and chemicals}

Curcumin (Columbus Chemical Industries, Inc. USA, suspended in $2 \%$ carboxy methyl cellulose (CMC)), metformin (Egyptian Pharmaceutical Company Chemical Industries Development (CID), dissolved in bidistilled water), CMC (Sigma-Chemical Company, USA), fructose (Winlab, UK), malondialdehyde bis-dimethylacetal (Merck, Germany) and thiobarbituric acid (MP Biomedicals Inc., France).

\section{Experimental design}

Animals of group I (normal control group) were maintained on drinking plane tap water (without fructose) and each rat was administered $2 \mathrm{ml}$ of $2 \% \mathrm{CMC}$ daily for eight weeks. The rats of Group II to Group VIII are FFR. They were allowed to drink fructose solution for 8 consecutive weeks to induce MetSyn (FFR) and simultaneously received the following treatments once daily orally by a stomach tube:

Group II: FFR received $2 \mathrm{ml}$ of $2 \% \mathrm{CMC}$ only.

Group III: FFR treated with curcumin (40 $\mathrm{mg} / \mathrm{kg}$ ).

Group IV: FFR treated with metformin (100 $\mathrm{mg} / \mathrm{kg}$ ).

Group V: FFR medicated concurrently with curcumin $(40 \mathrm{mg} / \mathrm{kg})$ and metformin $(100 \mathrm{mg} / \mathrm{kg})$.

Group VI: FFR treated with curcumin (80 $\mathrm{mg} / \mathrm{kg}$ ).

Group VII: FFR medicated with metformin $(200 \mathrm{mg} / \mathrm{kg})$.

Group VIII: FFR coadminstered curcumin (80 $\mathrm{mg} / \mathrm{kg})$ and metformin (200 $\mathrm{mg} / \mathrm{kg}$ ).

Animals were individually weighed at the start of the experiment and then weekly to adjust the doses. At the end of experimental period, each rat was weighed, measured nose to anus length and Lee index was calculated. The rats with Lee index values exceeding 300 were considered as being obese ${ }^{6}$.

Arterial blood pressure (ABP) measurement

At the end of 8 weeks experimental period, $\mathrm{ABP}$ of each rat was recorded by indirect (non invasive) method using LE 5001 Non Invasive Blood Pressure Meter (Panlab, Harvard). Rats were subjected to once daily trial for seven days before the experiment to be accommodated to the procedures and provide constant readings ${ }^{7}$.

\section{Insulin resistance (IR) and oral glucose tolerance test (OGTT)}

After ABP monitoring, rats were deprived of food for $12 \mathrm{hr}$. The fructose-supplemented drinking water was replaced with normal water for the food-deprivation period. After that, the basal blood glucose level (BGL) and insulin concentrations were measured in blood taken from the tail vein using enzymatic "glucosy kits" (Diamond Diagnostics, Cairo, Egypt) ${ }^{8}$ and 
a solid phase enzyme-linked immunosorbent assay (ELISA) kit (Immunospec Corporation, Canoga Park, USA) $)^{9}$, respectively.

Insulin resistance was calculated by the Homeostasis Model Assessment index of Insulin Resistance (HOMA-IR) ${ }^{10}$.

Rats were then given $25 \%$ glucose solution $(100 \mathrm{mg} / 100 \mathrm{~g}$ body weight) by oral gavage, blood samples were taken from the tail vein and OGTT was calculated ${ }^{11}$.

Animals were then sacrificed. Blood samples were suitably collected and sera were separated by centrifugation and frozen at $-20^{\circ} \mathrm{C}$ for further biochemical analysis. Visceral fat was removed, rinsed with saline, dried by filter paper and immediately weighed.

\section{Assessment of metabolic parameters}

Lipids were determined by enzymatic colorimetric Liquizyme Kits (Egyptian Company for Biotechnology, Cairo, Egypt) for triglycerides (TG), total cholesterol (TC) and high density lipoprotein-cholesterol (HDL-C) estimation. Low density lipoprotein-cholesterol (LDL-C) was measured by enzymatic colorimetric Kit (Biodiagnostic Laboratory, Giza, Egypt). All tests were performed according to the manufacture's guidelines.

\section{Assessment of oxidative stress parameters}

Malondialdehyde (MDA) and 8-iso$\mathrm{PGF}_{2 \alpha}$, as indicators of lipid peroxidation, were determined spectrophotometrically by "thiobarbituric acid reactive substances method" 12 and ELISA Kit (Glory Science Co., USA) respectively. Superoxide dismutase activity was measured by a colorimetric Kit (Biodiagnostics, Giza, Egypt).

\section{Assessment of inflammatory status parameters}

The ELISA Kits were used to measure serum levels of adiponectin, TNF- $\alpha$ (Assaypro, USA) and IL-6 (Ani Biotech Oy Orgenium Lboratories Business Unit, Finland). CRP was determined using Latex Reagent Kit (ATLAS MEDICAL, Cambridge, UK). All levels were quantified according to the instructions supplied with the kits.

\section{Statistical analysis}

Data are presented as mean \pm standard error of the mean (S.E.). Changes in the assessed parameters in different treatment groups, FFR group and non FFR (normal control) group were compared by one-way analysis of variance (ANOVA), followed by Newman-Keuls for multiple comparison, and Student's $\mathrm{t}$ test for significance. Analysis revealing P-value $<0.05$ was deemed to be statistically significant ${ }^{13}$. Statistical analysis was performed using GraphPad prism $^{\circledR}$ software, Inc version 5.

\section{RESULTS AND DISCUSSION}

\section{Results}

\section{Effects on metabolic parameters}

Feeding with fructose for 8 weeks resulted in induction of MetSyn-like condition in rats as indicated by the development of most features of the disease. For instance, it caused a significant increase in the serum glucose and insulin levels alongside with IGT and IR when compared to those of the normal control group (Fig. 1). In the same line, a significant increase in serum TG, TC and LDL-C together with decreased HDL-C were also recorded (Fig. 2).

Significant attenuation of the progression of these metabolic parameters by variable extents was observed in FFR which received curcumin (40 and $80 \mathrm{mg} / \mathrm{kg}$ ) and metformin (100 and $200 \mathrm{mg} / \mathrm{kg}$ ) either solely or in combinations as compared to FFR control group (Figs. 1\&2). However, the levels of these tested parameters were still significantly higher as compared to those of normal control group. The two combinations of curcumin and metformin exerted greater effects than that produced by either curcumin or metformin alone. Noticeably, the curcumin $(80 \mathrm{mg} / \mathrm{kg}) /$ metformin $(200 \mathrm{mg} / \mathrm{kg})$ combination appears to have the highest effectiveness. The last combination restores the normal levels of the tested parameters except those of lipid profile (Figs. 1\&2).

The ameliorating effects of the two dose levels of metformin (100 and $200 \mathrm{mg} / \mathrm{kg}$ ) on IR and IGT were significant comparing to those of curcumin $(40$ and $80 \mathrm{mg} / \mathrm{kg}$ ). In contrast, the improvement effects of the two dose levels of curcumin on lipid profile were significant as compared to those of metformin.

Induction of MetSyn in rats was associated with significant increase in weights of body and visceral fats together with development of obesity as indicated by the lee index (Table 1). 
BGL (A)

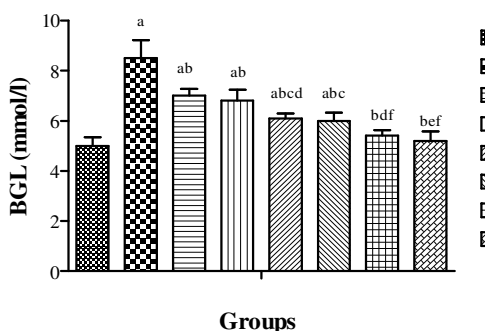

Insulin (C)

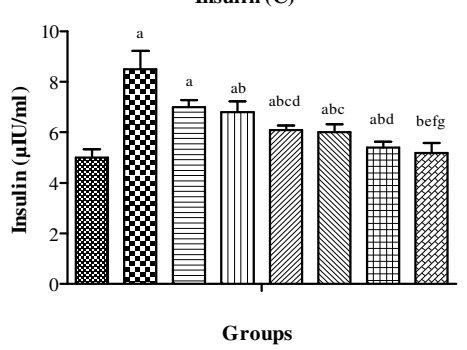

Normal control E FFR control

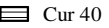

西 Met 100 Cur 40+Met100 Cur 80 Met 200 Cur 80+Met 200 Cur $80+\mathrm{Met} 200$

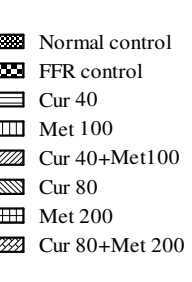
[ar Cur $80+$ Met 200
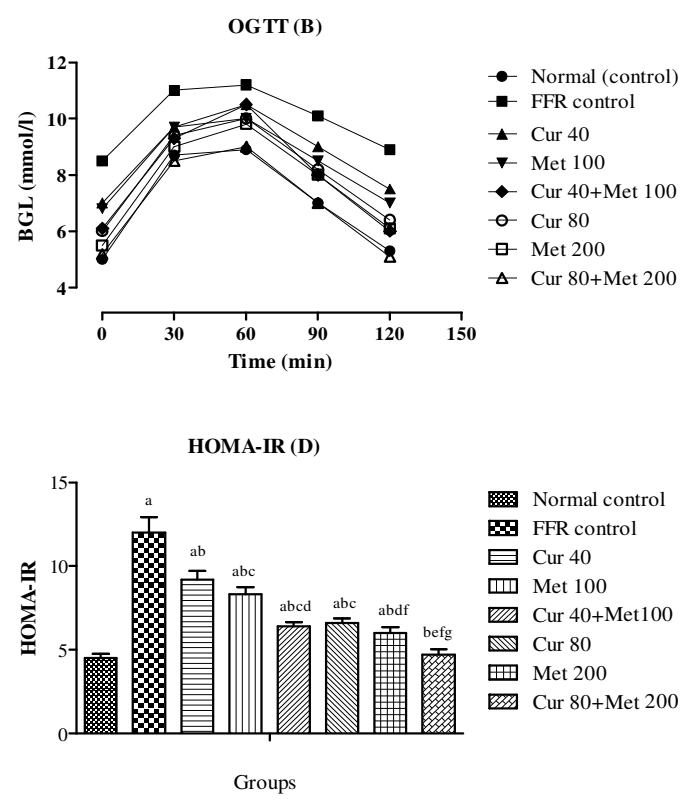

Fig. 1: Effects of various treatments on (A) BGL, (B) OGTT, (C) serum insulin and (D) HOMA-IR of different rat groups.

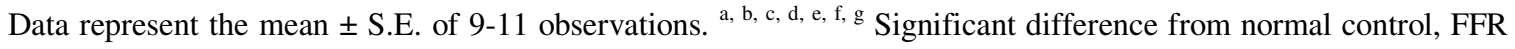
control, Cur 40, Met 100, Cur $40+$ Met 100, Cur 80 and Met 200, respectively, at $\mathrm{P}<0.05$.

FFR $=$ Fructose-fed rats, Cur $40=$ Curcumin $(40 \mathrm{mg} / \mathrm{kg} /$ day $)$, Cur $80=$ Curcumin $(80 \mathrm{mg} / \mathrm{kg} / \mathrm{day})$, Met $100=$ Metformin (100 mg/kg/day), Met $200=$ Metformin $(200 \mathrm{mg} / \mathrm{kg} /$ day $)$ and HOMA-IR = Homeostasis Model Assessment index of Insulin Resistance.

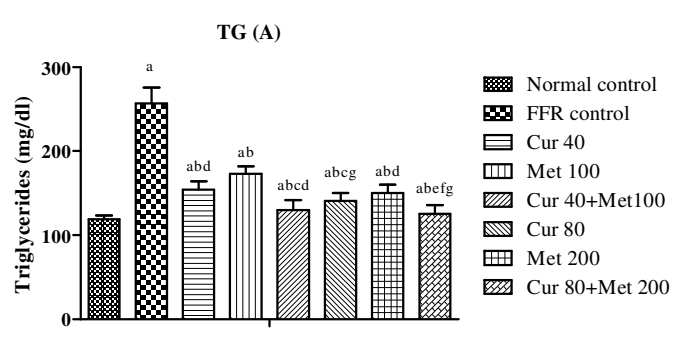

Groups

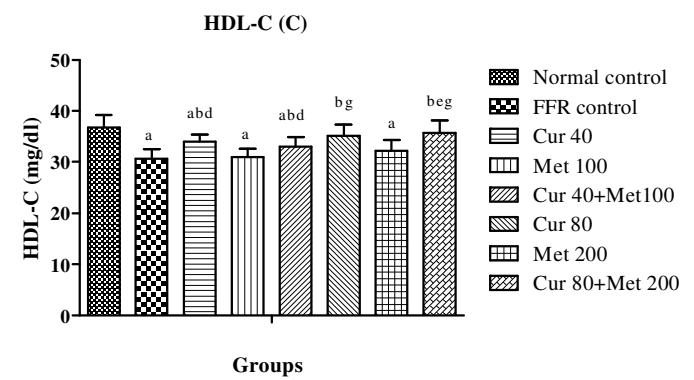

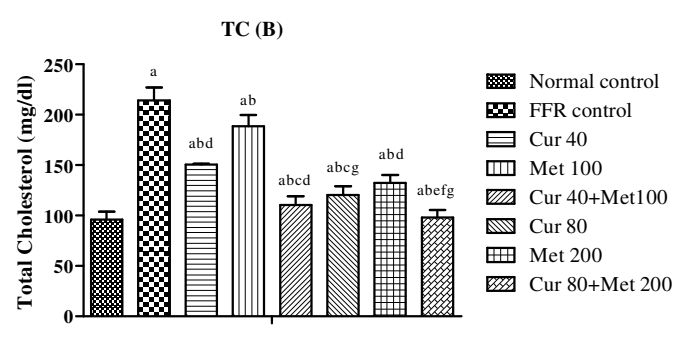

Groups

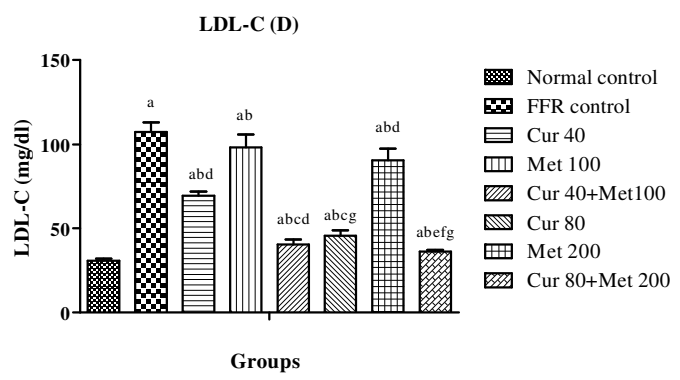

Fig. 2: Effects of various treatments on (A) Triglyceride, (B) Total Cholesterol, (C) HDL-C and (D) LDL-C of different rat groups.

Data represent the mean \pm S.E. of 9-11 observations. ${ }^{\text {a }, ~ b, ~ c, ~ d, ~ e, ~ f, ~ g ~}$ Significant difference from normal control, FFR control, Cur 40, Met 100, Cur $40+$ Met 100, Cur 80 and Met 200, respectively at $\mathrm{P}<0.05$.

FFR $=$ Fructose-fed rats, Cur $40=$ Curcumin $(40 \mathrm{mg} / \mathrm{kg} / \mathrm{day})$, Cur $80=$ Curcumin $(80 \mathrm{mg} / \mathrm{kg} / \mathrm{day})$, Met $100=$ Metformin $(100 \mathrm{mg} / \mathrm{kg} /$ day $)$ and Met $200=$ Metformin $(200 \mathrm{mg} / \mathrm{kg} / \mathrm{day})$. 
Table 1: Effects of various treatments on Body weight, Lee index and Visceral fat of different rat groups.

\begin{tabular}{|c|c|c|c|c|}
\hline Group & Treatment & $\begin{array}{l}\text { Final Body } \\
\text { weights }(\mathrm{g})\end{array}$ & Lee index & $\begin{array}{l}\text { Visceral fat Weight } \\
\text { (g/100 g body weight })\end{array}$ \\
\hline $\begin{array}{l}\text { Group I } \\
\text { Normal } \\
\text { (control) }\end{array}$ & $\begin{array}{l}2 \mathrm{ml} \text { daily orally of } 2 \% \mathrm{CMC} \text { for } \\
\qquad \text { weeks }\end{array}$ & $251.4 \pm 9.8$ & $287.2 \pm 9.6$ & $0.8 \pm 0.05$ \\
\hline $\begin{array}{l}\text { Group II } \\
\text { FFR } \\
\text { (control) } \\
\end{array}$ & $\begin{array}{l}10 \% \text { Fructose in drinking water } \\
+2 \text { ml daily orally of } 2 \% \mathrm{CMC} \\
\text { for } 8 \text { weeks }\end{array}$ & $311.4 \pm 14.5^{\mathrm{a}}$ & $305.5 \pm 10.1$ & $2.0 \pm 0.08^{\mathrm{a}}$ \\
\hline $\begin{array}{l}\text { Group III } \\
\text { FFR } \\
\text { (treated) }\end{array}$ & $\begin{array}{c}\text { Curcumin }(40 \mathrm{mg} / \mathrm{kg} / \text { day) orally } \\
\text { for } 8 \text { weeks }\end{array}$ & $270.0 \pm 12.4^{\mathrm{ab}}$ & $293.2 \pm 13.2$ & $1.8 \pm 0.11^{\mathrm{a}}$ \\
\hline $\begin{array}{l}\text { Group IV } \\
\text { FFR } \\
\text { (treated) }\end{array}$ & $\begin{array}{l}\text { Metformin }(100 \mathrm{mg} / \mathrm{kg} / \text { day }) \\
\text { orally for } 8 \text { weeks }\end{array}$ & $227.8 \pm 14.8^{\mathrm{abc}}$ & $288.0 \pm 9.3$ & $1.7 \pm 0.04^{\mathrm{a}}$ \\
\hline $\begin{array}{l}\text { Group V } \\
\text { FFR } \\
\text { (treated) }\end{array}$ & $\begin{array}{l}\text { Curcumin }(40 \mathrm{mg} / \mathrm{kg} / \text { day })+ \\
\text { Metformin }(100 \mathrm{mg} / \mathrm{kg} / \text { day }) \\
\text { orally for } 8 \text { weeks } \\
\end{array}$ & $215.0 \pm 19.7^{\mathrm{abcd}}$ & $275.5 \pm 10.7$ & $1.2 \pm 0.02^{\mathrm{abcd}}$ \\
\hline $\begin{array}{l}\text { Group VI } \\
\text { FFR } \\
\text { (treated) }\end{array}$ & $\begin{array}{c}\text { Curcumin }(80 \mathrm{mg} / \mathrm{kg} / \mathrm{day}) \text { orally } \\
\text { for } 8 \text { weeks }\end{array}$ & $265.3 \pm 17.0^{\mathrm{ab}}$ & $290.2 \pm 8.9$ & $1.5 \pm 0.07^{\mathrm{ab}}$ \\
\hline $\begin{array}{c}\text { Group } \\
\text { VII } \\
\text { FFR } \\
\text { (treated) } \\
\end{array}$ & $\begin{array}{l}\text { Metformin }(200 \mathrm{mg} / \mathrm{kg} / \text { day }) \\
\quad \text { orally for } 8 \text { weeks }\end{array}$ & $219.0 \pm 16.5^{\text {abdf }}$ & $287.6 \pm 11.5$ & $1.3 \pm 0.09^{\mathrm{abd}}$ \\
\hline $\begin{array}{l}\text { Group } \\
\text { VIII } \\
\text { FFR } \\
\text { (treated) }\end{array}$ & $\begin{array}{l}\text { Curcumin }(80 \mathrm{mg} / \mathrm{kg} / \mathrm{day})+ \\
\text { Metformin }(200 \mathrm{mg} / \mathrm{kg} / \text { day }) \\
\text { orally for } 8 \text { weeks }\end{array}$ & $\begin{array}{l}205.0 \pm \\
15.6^{\text {abefg }}\end{array}$ & $272.3 \pm 12.4$ & $1.0 \pm 0.06^{\mathrm{bf}}$ \\
\hline
\end{tabular}

Data represent the mean \pm S.E. of 10-11 observations.

a, b, c, d, e, f, g Significant difference from normal control, FFR control, Group III, Group IV, Group V, Group VI and Group VII, respectively, at $\mathrm{P}<0.05$.

FFR $=$ Fructose-fed rats.

Curcumin in its two dose levels (40 and 80 $\mathrm{mg} / \mathrm{kg}$ ) significantly decreased the body weights of rats as compared with FFR control group, but still higher than those of normal control group. In contrast, metformin in its two dose levels significantly decreased the rats' body weights below their normal values. The high dose levels of each of curcumin (80 $\mathrm{mg} / \mathrm{kg})$ and metformin (200 $\mathrm{mg} / \mathrm{kg})$ significantly decreased the visceral fat weights as compared with the FFR control group, but still significantly higher than those of normal control group. No significant differences in the weight of visceral fats were observed in rats treated with the low dose levels of each of curcumin $(40 \mathrm{mg} / \mathrm{kg})$ and metformin (100 $\mathrm{mg} / \mathrm{kg}$ ). A marked significant decrease in weights of both body and visceral fat was recorded in rats administered the two drug combinations particularly those which received curcumin $(80 \mathrm{mg} / \mathrm{kg})$ plus metformin $(200$ $\mathrm{mg} / \mathrm{kg}$ ). An abolishment of obesity was observed in all FFR administered the different doses of drugs under investigation (Table 1).

\section{Effects on arterial blood pressure (ABP)}

Data of the present study showed a significant elevation in ABP from $118.1 \mathrm{mmHg}$ for normal control group to $144.7 \mathrm{mmHg}$ after 8 weeks of fructose feeding.

Curcumin in its two dose levels (40 and 80 $\mathrm{mg} / \mathrm{kg}$ ) significantly decreased the ABP to the 
levels of 137.0 and $130.4 \mathrm{mmHg}$, respectively, as compared to that of FFR control group, but still higher than those of normal control group. No significant changes in $\mathrm{ABP}$ were observed in rats treated with either doses of metformin (100 and $200 \mathrm{mg} / \mathrm{kg}$ ). The normal level of ABP was almost restored in rats coadminstered with curcumin $(80 \mathrm{mg} / \mathrm{kg})$ plus metformin (200 $\mathrm{mg} / \mathrm{kg}$ ).

\section{Effects on oxidative stress parameters}

In FFR, concentrations of MDA and 8-iso$\mathrm{PGF}_{2 \alpha}$ were significantly increased while the activity of SOD was significantly decreased as compared to normal control group (Fig. 3).

These disturbances in the oxidative stress profile associated with MetSyn were variably corrected in rats treated with each of the two dose levels of the curcumin or metformin and their combinations. Marked correction of these disturbances was observed in rats which concurrently administered curcumin $\quad(80$ $\mathrm{mg} / \mathrm{kg}$ ) with metformin $(200 \mathrm{mg} / \mathrm{kg})$. The effects of the low $(40 \mathrm{mg} / \mathrm{kg})$ and high $(80$ $\mathrm{mg} / \mathrm{kg}$ ) doses of curcumin appears to differ significantly from the respective doses (100 and $200 \mathrm{mg} / \mathrm{kg}$ ) of metformin.
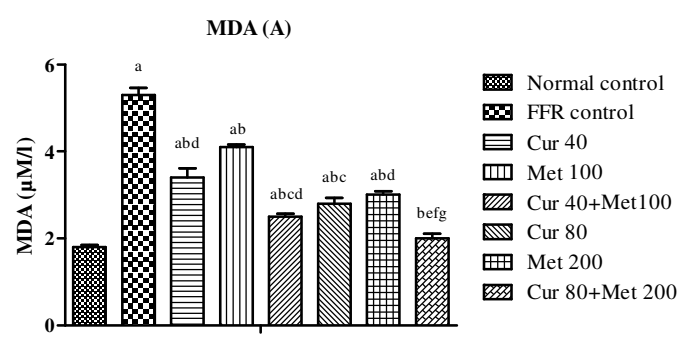

Groups

\section{Effects on inflammatory status parameters}

Induction of MetSyn was accompanied by elevation in the serum levels of the proinflammatory cytokines (TNF- $\alpha$ and IL-6) and marker (CRP) concomitantly with decreased in the anti-inflammatory adiponectin as compared to their respective values in normal control group (Fig. 4).

Treatment of FFR with curcumin (40 and $80 \mathrm{mg} / \mathrm{kg}$ ) and metformin (100 and $200 \mathrm{mg} / \mathrm{kg}$ ) either singly or concurrently caused significant decrease in TNF- $\alpha$, IL- 6 and CRP together with increase in adiponectin levels when compared to FFR control group. Moreover, concurrent administration of curcumin (80 $\mathrm{mg} / \mathrm{kg})$ with metformin $(200 \mathrm{mg} / \mathrm{kg})$ led to significant reduction in the serum levels of these parameters to almost their levels in normal control group. The effects of the low $(40 \mathrm{mg} / \mathrm{kg})$ and high $(80 \mathrm{mg} / \mathrm{kg})$ doses of curcumin appears to be significantly different from the respective doses $(100$ and $200 \mathrm{mg} / \mathrm{kg}$ ) of metformin.

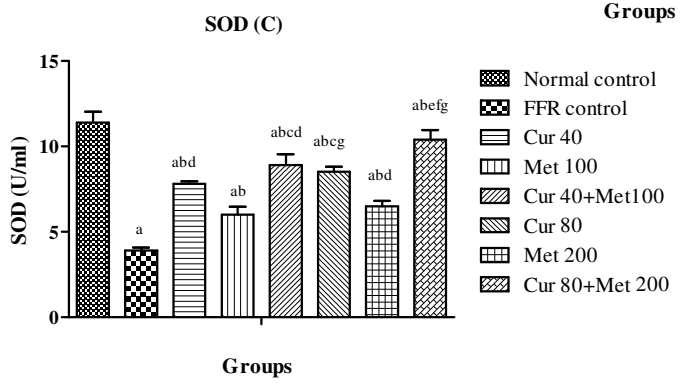

Fig. 3: Effects of various treatments on oxidative stress parameters (A) MDA, (B) 8-Iso-PGF $2 \alpha$ and (C) SOD of different rat groups.

Data represent the mean \pm S.E. of 9-10 observations. ${ }^{\text {a }, ~ b, ~ c, ~ d, ~ e, ~ f, ~ g ~ S i g n i f i c a n t ~ d i f f e r e n c e ~ f r o m ~ n o r m a l ~ c o n t r o l, ~ F F R ~}$ control, Cur 40, Met 100, Cur $40+$ Met 100, Cur 80 and Met 200, respectively at $\mathrm{P}<0.05$.

FFR $=$ Fructose-fed rats, Cur $40=$ Curcumin $(40 \mathrm{mg} / \mathrm{kg} / \mathrm{day})$, Cur $80=$ Curcumin $(80 \mathrm{mg} / \mathrm{kg} / \mathrm{day})$, Met $100=$ Metformin $(100 \mathrm{mg} / \mathrm{kg} /$ day $)$, Met $200=$ Metformin $(200 \mathrm{mg} / \mathrm{kg} / \mathrm{day}), \mathrm{MDA}=$ Malondialdehyde, 8 -Iso-PGF $\mathrm{P}_{2 \alpha}=8$ Iso-Prostaglandin $\mathrm{F}_{2 \alpha}$ and $\mathrm{SOD}=$ Superoxide Dismutase. 

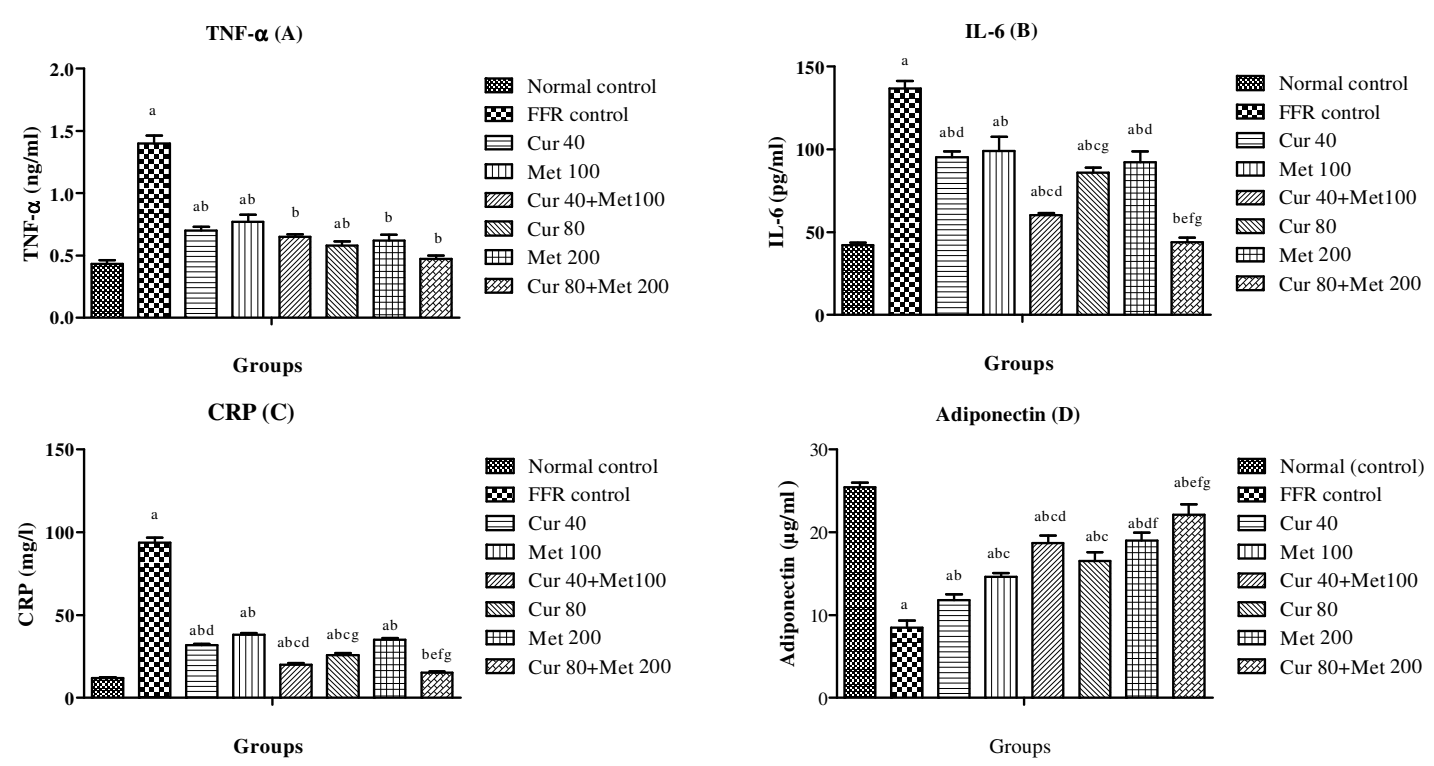

Fig. 4: Effects of various treatments on (A) TNF- $\alpha$, (B) IL-6, (C) CRP and (D) adiponectin of different rat groups.

Data represent the mean \pm S.E. of 9-10 observations. ${ }^{\text {a, b, c, d, e, f, g }}$ Significant difference from normal control, FFR control, Cur 40, Met 100, Cur $40+$ Met 100, Cur 80 and Met 200, respectively at $\mathrm{P}<0.05$.

FFR $=$ Fructose-fed rats, Cur $40=$ Curcumin $(40 \mathrm{mg} / \mathrm{kg} /$ day $)$, Cur $80=$ Curcumin $(80 \mathrm{mg} / \mathrm{kg} /$ day $)$, Met $100=$ Metformin (100 mg/kg/day), Met 200 = Metformin (200 mg/kg/day), TNF- $\alpha=$ Tumor Necrosis Factor-alpha, IL-6

$=$ Interleukin-6 and CRP $=$ C-reactive protein.

\section{Discussion}

The prevalence of MetSyn is rising rapidly even in developing countries; the condition is proving to be a common precursor of cardiovascular diseases and type 2 diabetes. Measures therefore are required to prevent the associated complications ${ }^{1}$.

High fructose diet has been shown to induce clustering signs of MetSyn in several animal models ${ }^{14}$. In the current study, feeding rats with fructose for 8 weeks developed the previously repeatedly reported cardinal features of MetSyn. Thus, FFR exhibited hyperglycemia, hyperinsulinemia, IGT and higher value of IR-index comparing to control group. Meanwhile, FFR showed dyslipidemia as reflected by significant elevation in serum TG and TC levels accompanied by increased value of LDL-C with decreased HDL-C level. Additionally, feeding of rats with fructose caused elevation in body weight gain, weight of visceral fats and obesity-index together with moderate rising in ABP.

Existing evidence points to multitude of molecular mechanisms involved in the development of these observed interrelated metabolic abnormalities. High consumption of fructose stimulates hepatic lipogenesis with consequent increased formation of fatty acids, TG and lipoproteins through several metabolic pathways. Excess intracellular lipids is thought to cause dysfunctional insulin signaling, hence impairs insulin actions and utilization of glucose leading to hyperglycemia, hyperinsulinemia, IGT and $\mathrm{IR}^{15}$. The accumulation of fats together with increased calories intake resulted in increased fat mass and obesity which closely interwined with $\mathrm{IR}^{16}$. Compensatory hyperinsulinemia has been thought to be a cause of hypertension since insulin could cause sympathetic overactivity, sodium retention and vascular smooth muscle proliferation ${ }^{17}$.

Data of the present study provide a direct evidence for the potential role of oxidative stress in the development of MetSyn's events in FFR. This is deduced by significant elevation of the serum levels of MDA and 8-iso-PGF ${ }_{2 \alpha}$ in these rats which are formed as main end products of lipid peroxidation and served as indicators of oxidative stress intensity ${ }^{18}$ alongside with reduced activity of the antioxidant enzyme SOD. Similarly, the production of 8 -iso- $\mathrm{PGF}_{2 \alpha}$ through the non 
enzymatic oxidation of arachidonic acid by ROS is markedly increased in MetSyn ${ }^{19}$. Increased lipid peroxidation could be secondary to hyperglycemia as fructose in higher concentrations provides oxidative environment ${ }^{20}$. The decrease in SOD activity in the present study could be due to a feedback inhibition or oxidative inactivation of enzyme proteins due to excessive ROS generation. The significant increase in lipid peroxidation and reduction in SOD activity in the current study gained support from the concept that increased oxidative stress may play an important role in the progression of MetSyn related manifestations including dyslipidemia, hyperglycemia, IR and hypertension. The ROS activate serine/threonine kinase cascade that eventually phosphorylate insulin receptors resulting in $\mathrm{IR}^{21}$. Additionally, ROS dysregulate expression of inflammation related adipocytokines in the MetSyn condition through stimulation of redox-sensitive transcription factors particularly nuclear factorkappa B (NF-kB) ${ }^{22}$.

The present data revealed that FFR exhibited increased levels of the proinflammatory cytokines (TNF- $\alpha$ and IL-6) and marker (CRP) with decreased level of the antiinflammatory adipokine, adiponectin. The observed abnormalities in these assessed parameters that could be assumed to be linked to the increase in body mass, as indicated by higher obesity-index and increased visceral fat of these rats. This assumption gained support from the quite recent concept that adipose tissue particularly visceral fats is the main source of cytokines that constitute major mediators in the inflammatory states of $\mathrm{MetSyn}^{22}$. Emerging laboratory and clinical evidence have provided strong relationship between CRP and various features of MetSyn. Furthermore, Ridker et $a l .{ }^{23}$ claimed that CRP be added as a clinical criterion of MetSyn. In the same line, the cytokines TNF- $\alpha$ and IL-6 may activate components of inflammatory pathways such as NF-kB and inactivate insulin receptor substrate-1 (IRS-1) and thereby, inhibit insulin signaling with consequent IR, type 2 diabetes and cardiovascular events ${ }^{24}$. In contrast, adiponectin is known to inhibit the activity of NF- $\kappa B$, increase insulin sensitivity and improve lipid profile ${ }^{25}$. Additionally, the serum adiponectin is reduced in obese human and animals ${ }^{26}$ as exactly seen in the current study. The observed reciprocal relationship of CRP and adiponectin in this study has been also documented by Sugiura et $a l^{27}$ who reported that adiponectin could decrease CRP synthesis and secretion.

The results of the current study revealed that coadministration of the two dose levels of curcumin (40 and $80 \mathrm{mg} / \mathrm{kg}$ ) and metformin (100 and $200 \mathrm{mg} / \mathrm{kg}$ ) with fructose for 8 weeks ameliorated, to various extents, all the assessed parameters of MetSyn as compared to those of fructose fed control group. Noticeably, more pronounced effects were observed with the high doses of curcumin $(80 \mathrm{mg} / \mathrm{kg})$ and metformin $(200 \mathrm{mg} / \mathrm{kg})$ compared with the corresponding small doses $(40$ and $100 \mathrm{mg} / \mathrm{kg}$, respectively). Accordingly, it can be cautiously believed that the effects of the two drugs seem to be dose-dependent.

This study indicated that each of curcumin and metformin treatment of FFR caused an improvement of hyperglycemia and IGT together with the reduction of elevated serum insulin levels. This is probably may occur secondary to the reduction in the hallmark of MetSyn progression, IR, as indicated by reduced HOMA-IR index in these rats. Decreased IR and/or improved insulin sensitivity are thought to stimulate glucose disposal and therefore, attenuate hyperglycemia and hyperinsulinemia. These results are in harmony with those of Seo et al. ${ }^{28}$ who documented the improvement of IGT and insulin sensitivity in FFR treated with curcumin. The benefits of curcumin as a hypoglycemic agent have been repeatedly established in both diabetic rats $^{29}$ and patients $^{30}$. The hypoglycemic effect of curcumin was attributed to reduction in glucose output, improvement of insulin sensitivity via activation of PPAR- $\gamma^{31}$ and protection of glucose transporter-1 (GLUT-1) ${ }^{32}$. Meanwhile, the antihyperglycemic effects of the insulin sensitizing agent, metformin, have been extensively reported and documented. These effects could be primarily mediated by inhibition of mitochondrial respiratory chain complex $\mathrm{I}^{33}$, activation of AMP-activated protein kinase (AMPK) which regulate glucose and fat metabolism and upregulation of insulin receptors $^{34}$. 
In the present study, curcumin significantly decreased body weight and improved obesity-index of FFR as compared with FFR control group. However, the rats' weights at the end of the study were still higher than those of normal control group. Likewise, metformin produced remarkable significant decrease in body weight of FFR below their normal values. Similarly, previous studies elucidated the ability of curcumin to inhibit angiogenesis in adipose tissues, decreased differentiation of preadipocytes and reduced accumulation of lipids in adipocytes that result in lowering of body weight ${ }^{35}$. Moreover, the weight loss during metformin medication to obese $^{36}$ and non obese diabetic patients ${ }^{37}$ was remarked. The observed surpassing lowering effect of metformin comparing to that of curcumin on body weights of FFR, could be attributed to other favorable effects of metformin beyond its well known antihyperglycemic and insulin sensitizing characteristics. This presumably could be related to a decrease net caloric intake through appetite suppression, induction of lipolysis and reduction of the levels of leptin ${ }^{38}$ and ghrelin ${ }^{39}$.

It is worth here to mention that the elevated ABP induced by fructose was significantly reduced upon treatment with curcumin. This can be explained on the basis of the notion that hyperinsulinemia and IR are intrinsically linked to the pathogenesis of hypertension in $\mathrm{FFR}^{17}$. It is therefore suggested that the reversal of these metabolic disturbances by curcumin could result in a concomitant lowering in ABP. This explanation is consistence with that emerged by Khan et $a l .{ }^{40}$. Although it was reported that metformin, in relatively large doses, caused lowering in ABP in diabetic hypertensive rats ${ }^{41}$ and patients ${ }^{42}$. However, in this study metformin caused insignificant reduction in ABP. Similarly, clinical trial indicated the same results in diabetic hypertensive patients ${ }^{43}$.

The present study indicated that curcumin and metformin served as antidyslipidemic agents as it is evident by the improvement of the disturbed lipid profile in FFR. In this respect, the effects of curcumin were generally more pronounced in comparison to those of metformin. The fact that IR causes excessive accumulation of carbohydrates which in turn can lead to increase in lipid production ${ }^{15}$ should be born in mind. The hypolipidemic effect of both drugs might be secondary to their insulin sensitizing effects. This idea is substantiated by the observed restoration of the reduced levels of adiponectin in the treated rats which can be positively correlated with increased insulin sensitivity. Moreover, it has been suggested that curcumin via its activation of cholesterol $7 \alpha$-hydroxylase enzyme and upregulation of hepatic LDL receptors may stimulate cholesterol catabolism ${ }^{44}$. Metformin may also inhibit lipogenesis secondary to AMPK activation ${ }^{45}$.

The protective effects of either curcumin or metformin against fructose induced MetSyn in rats was accompanied with abrogation of increased oxidative stress. Both two drugs reduced the elevated serum levels of lipid peroxidation markers, MDA and 8 -iso- $\mathrm{PGF}_{2 \alpha}$, together with restoration of the activity of the antioxidant enzyme SOD. Our results are in harmony with those previously reported which postulated that the antioxidant mechanisms of curcumin included its ability to scavenge variety of ROS owing to its phenolic structure; reduction of ROS production through NADPH oxidase suppression ${ }^{46}$ and inhibition of oxidative enzymes like cytochrome $\mathrm{P} 450^{47}$. The antioxidant potentiality of metformin also has been assumed by Bonnefont-Rousselot et $a l^{48}$ and subsequently by Ouslimani et $a l^{49}$. They reported that metformin is able to scavenge free radicals either by reducing NADPH oxidase or respiratory chain reactions in mitochondria. In the present study, the amelioration of oxidative stress was significant in curcumin treated rats as compared to the metformin groups. This is in good agreement with the finding that the antioxidant capacity of curcumin is 100 fold stronger than that of vitamin $\mathrm{C}$ and $\mathrm{E}^{50}$ while that of metformin is only comparable to vitamin $\mathrm{E}^{51}$.

Data of the present study provide clearly a direct evidence for the anti-inflammatory activity of each of curcumin and metformin. This was deduced by the significant reduction in the serum levels of the pro-inflammatory cytokines (TNF- $\alpha$ and IL-6) and marker (CRP) together with elevation in the levels of the antiinflammatory adipokine, adiponectin. Curcumin is observed to lower these inflammatory parameters better than metformin. These effects were also concur with 
significant decrease in the weight of visceral fat which quite recently is recognized to be the main source of these adipocytokines ${ }^{22}$. These results are in agreement with those of Usharani et $a ._{.}{ }^{52}$ who observed reduction in the levels of TNF- $\alpha$, IL-6 and CRP in diabetic patients treated with curcumin, and in hypertensive dyslipidemic patients receiving metformin ${ }^{53}$. It was assumed that direct suppression of NF- $\mathrm{\kappa B}$ activity and activation of PPAR- $\gamma$ by each of curcumin $^{54}$ and metformin ${ }^{55}$ could lead to downmodulation of the expression of genes involved in pro-inflammatory cytokine synthesis. In addition, adiponectin is able to suppress NF-KB activity ${ }^{25}$. We must take in consideration the fact that reduction in ROS inhibits NF- $\mathrm{\kappa B}$ and modulates the secretion of adipocytokines. The observed antioxidant properties of curcumin and metformin may be contributed in their anti-inflammatory activities. This possible inference is tempting to speculate that the improvement of oxidative stress and inflammatory status in FFR displayed by the two drugs, resulted in restoration of insulin signaling and reduction of IR.

Interestingly, the progression of MetSyn features in FFR not only improved but seems even to be normalized when curcumin ( 80 $\mathrm{mg} / \mathrm{kg})$ and metformin (200 $\mathrm{mg} / \mathrm{kg})$ were concurrently administered. As mentioned before, the two drugs under investigation display multiple effects on clustering signs of MetSyn. Therefore, it is plausible to suggest that the enhancement of their protective effect upon their combination might be relevant to their complementary mechanisms.

In conclusion, the significant findings of the present study indicate that curcumin was fairly superior or at least comparable to the well known antihyperglycemic, insulin sensitizing agent, metformin in protecting rats against fructose-induced MetSyn. The protective effectiveness of the two drugs was clearly augmented upon their combined administration. The confirmed efficacy of the two drugs appears to be mediated partially, through their antioxidant and antiinflammatory effects. Lastly, the important findings and conclusions reached in the present study on the rat encourage future confirmatory studies to substantiate the possible clinical use of curcumin as a protective agent against the serious condition of MetSyn. Elucidation of the pleiotropic actions of curcumin at the molecular level also represents an important target for prospective plan of study. Further studies are under current investigation to achieve more definite conclusions.

\section{REFERENCES}

1- D. E. Moller and K. D. Kaufman, "Metabolic syndrome: A clinical and molecular perspective", Annu. Rev. Med., 56, 45-62 (2005).

2- P. Shankar and M. Sundarka, "Metabolic syndrome: Its pathogenesis and management", JIACM, 4, 275-281 (2003).

3- I. Chattopadhyay, K. Biswas, U. Bandyopadhyay and R. K. Banerjee, "Turmeric and curcumin: Biological actions and medicinal applications", Curr. Sci., 87, 44-53 (2004).

4- S. C. Gupta, S. Prasad, J. H. Kim, S. Patchva, L. J. Webb, I. K. Priyadarsinic and B. B. Aggarwal, "Multitargeting by curcumin as revealed by molecular interaction studies", Nat. Prod., 28, $1937-$ 1955 (2011).

5- S. Dai and J. H. McNeill, "Fructoseinduced hypertension in rats is concentration- and duration-dependent", JPM, 33, 101-107 (1995).

6- L. L. Bernardis and B. D. Peterson, "Correlation between Lee index and carcass fat content in weaning and adult female rats with hypothalamic lesions", $\boldsymbol{J}$. Endocrinol., 40, 527-528 (1968).

7- M. Pauline, S. T. Avadhany and K. N. Maruthy, "Non invasive measurement of systolic blood pressure in rats: A simple technique", AJMS , 4, 365-369 (2011).

8- P. Trinder, "Determination of blood glucose using an oxidative-peroxidase system with a non-carcinogenic chromogen", J. Clin. Pathol., 22, 158-161 (1969).

9- C. R. Kahn and A. S. Rosenthal, "Immunologic reactions to insulin, insulin allergy, insulin resistance and autoimmune insulin syndrome", Diabetes Care, 2, 283295 (1979). 
10- D. R. Matthewa, J. P. Hisker and A. S. Rudenski, "Homeostasis model assessment: Insulin and beta-cell function from fasting plasma glucose and insulin concentration in man", Diabetologia, 28, 412-419 (1985).

11- M. M. Abdullah, Z. Xu, G. N. Pierce and M. H. Moghadasian, "The effects of simultaneous administration of dietary conjugated linoleic acid and telmisartan on cardiovascular risks in rats", Lipids, 42 , 855-864 (2007).

12- H. Ohkawa, N. Ohishi and K. Yagi, "Assay for lipid peroxides in animal tissues by thiobarbituric acid reaction", Analyt. Biochem., 95, 351-358 (1979).

13- M. F. Festing and D. G. Altman, "Guidelines for the design and statistical analysis of experiments using laboratory animals", ILAR J., 43, 244-258 (2002).

14- A. A. de Artin ano and M. M. Castro, "Experimental rat models to study the metabolic syndrome", Br. J. Nutr., 102, 1246-1253 (2009).

15- B. Mlinar, J. Marc, A. Janez and M. Pfeifer, "Molecular mechanisms of insulin resistance and associated diseases", Clin. Chim. Acta., 375, 20-35 (2007).

16- L. Tappy and K. A. Le, "Metabolic effects of fructose and the worldwide increase in obesity", Physiol. Reviews, 90, 23-46 (2010).

17- S. Verma, S. Bhanot and J. H. McNeill, "Sympathectomy prevents fructoseinduced hyperinsulinemia and hypertension", Eur. J. Pharmacol., 373, R1-R4 (1999).

18- M. D. Bagatini, C. C. Martins and V. Battisti, "Oxidative stress versus antioxidant defenses in patients with acute myocardial infarction", Heart and Vessels, 26, 55-63 (2011).

19- S. Tacconelli, M. L. Capone and P. Patrignani, "Measurement of 8-isoprostaglandin $\mathrm{F}_{2}$ alpha in biological fluids as a measure of lipid peroxidation", Methods in Mol. Biol., 644, 165-178 (2010).

20- J. Busserolles, E. Rock, E. Gueux and A. Mazur, "Short term consumption of a high sucrose diet has a pro-oxidant effect in rats", Br. J. Nutr., 87, 337-342 (2002).
21- J. L. Evans, B. A. Maddux and I. D. Goldfine, "The molecular basis for oxidative stress-induced insulin resistance", Antioxid. Redox Signal, 7, 1040-1052 (2005).

22- H. Waki and P. Tontonoz, "Endocrine functions of adipose tissue", Annu. Rev. Pathol., 2, 31-56 (2007).

23- P. M. Ridker, C. H. Hennekens, J. E. Buring and N. Rifai, "C-reactive protein and other markers of inflammation in the prediction of cardiovascular disease in women", Engl. J. Med., 342, 836-843 (2000).

24- J. Hirosumi, G. Tuncman, L. Chang, C. Z. Gorgun, K. T. Uysal, K. Maeda, M. Karin and G. S. Hotamisligil, "A central role for JNK in obesity and insulin resistance", Nat., 420, 333-336 (2002).

25- N. Ouchi, S. Kihara, Y. Arita, Y. Okamoto and K. Maeda, "Adiponectin, an adipocyte-derived plasma protein, inhibits endothelial NF-kappaB signaling through a cAMP-dependent pathway", Circulation, 102, 1296-1301 (2000).

26- Y. Arita, S. Kihara and N. Ouchi, "Paradoxical decrease of an adiposespecific protein, adiponectin, in obesity", Biochem. Biophysiol. Res. Commun., 257, 79-83 (1999).

27- K. Sugiura, K. Tamakoshi and H. Yatsuya, "Contribution of adipocytokines to lowgrade inflammatory state as expressed by circulating C-reactive protein in Japanese men: Comparison of leptin and adiponectin", Int. J. Cardiol., 130, 159164 (2008).

28- K. I. Seo, M. S. Choi, U. J. Jung, H. J. Kim, J. Yeo, S. M. Jeon and M. K. Lee, "Effect of curcumin supplementation on blood glucose, plasma insulin, and glucose homeostasis related enzyme activities in diabetic db/db mice", Mol. Nutr. Food Res., 52, 995-1004 (2008).

29- B. B. Aggarwal and K. B. Harikumar, "Potential therapeutic effects of curcumin, the anti-inflammatory agent, against neurodegenerative, cardiovascular, pulmonary, metabolic, autoimmune and neoplastic diseases", Int. J. Biochem. and Cell Biol., 41, 40-59 (2009). 
30- P. Faizal, S. Suresh, R. S. Kumar and K. T. Augusti, "A study on the hypoglycemic and hypolipidemic effects of an ayurvedic drug rajanyamalakadi in diabetic patients", Ind. J. Clin. Biochem., 24, 82-87 (2009).

31- L. X. Na, Y. L. Zhang, Y. Li, L. Y. Liu, R. Li, T. Kong and C. H. Sun, "Curcumin improves insulin resistance in skeletal muscle of rats", Nutr. Metab. Cardiovasc. Dis., 21, 526-533 (2011).

32- S. Rungseesantivanon, N. Thenchaisri, P. Ruangvejvorachai, S. Patumraj and N. Rungseesantivanon, "Curcumin supplementation could improve diabetesinduced endothelial dysfunction associated with decreased vascular superoxide production and PKC inhibition", BMC Complement. Alter. Med., 10, 1-9 (2010).

33- M. R. Owen, E. Doran and A. P. Halestrap, "Evidence that metformin exerts its anti-diabetic effects through inhibition of complex 1 of the mitochondrial respiratory chain", Biochem. J., 348, 607- 614 (2000).

34- J. E. Gunton, P. J. Delhanty, S. Takahashi and R. C. Baxter, "Metformin rapidly increases insulin receptor activation in human liver and signals preferentially through insulin-receptor substrate-2", $J$. Clin. Endocrinol. Metab., 88, 1323-1332 (2003).

35- A. Ejaz, D. Wu, P. Kwan and M. Meydani, "Curcumin inhibits adipogenesis in 3t3-L1 adipocytes and angiogenesis and obesity in C57/BL mice", J. Nutr., 139, 919-925 (2009).

36- A. Fontbonne, I. Diouf and M. BaccaraDinet, "Effects of 1-year treatment with metformin on metabolic and cardiovascular risk factors in diabetic upper-body obese subjects with mild glucose anomalies: A post-hoc analysis of the BIGPRO1 trial", Diabetes Metab., 35, 385-391 (2009).

37- K. Johansen, "Efficacy of metformin in the treatment of NIDDM. Meta-analysis", Diabetes Care, 22, 33-37 (1999).

38- A. Schultes, K. M. Oltmanns and W. Kern, "Modulation of hunger by plasma glucose and metformin", J. Clin. Endocrinol. Metab., 88, 1133-1141 (2003).
39- I. Kusaka, S. Nagasaka, H. Horie and S. Ishibashi, "Metformin, but not pioglitazone, decreases postchallenge plasma ghrelin levels in type 2 diabetic patients: A possible role in weight stability", Diabetes Obes. Metab., 10, 1039-1046 (2008).

40- S. H. Khan, F. A. Khan, A. Ijaz, A. Sattar, M. Dilwar and R. Hashim, "Hypertension and metabolic syndrome: Impact of clustering of hypertension in subjects with metabolic syndrome", Pak. Med. Sci., 23, 903-908 (2007).

41- P. V. Katakam, M. R. Ujhelyi, M. Hoenig and A. W. Miller, "Metformin improves vascular function in insulin-resistant rats", Hypertens., 35, 108-120 (2000).

42- A. Giugliano, A. Quatraro, G. Consoli, A. Minei, A. Ceriello and N. De Rosa, "Metformin for obese, insulin-treated diabetic patients: Improvement in glycaemic control and reduction of metabolic risk factors", Eur. J. Clin. Pharmacol., 44, 107-12 (1993).

43- M. G. Wulffelé, A. Kooy, D. de Zeeuw, C. D. Stehouwer and R. T. Gansevoort, "The effect of metformin on blood pressure, plasma cholesterol and triglycerides in type 2 diabetes mellitus: A systematic review", J. Int. Med., 256, 1-14 (2004).

44- M. C. Houston, S. Fazio and F. H. Chilton, "Nonpharmacologic treatment of dyslipidemia", Progress in Cardiovasc. Dis., 52, 61-94 (2009).

45- A. Cool , B. Zinker, W. Chiou, L. Kifle, N. Cao, M. Perham, R. Dickinson, A. Adler and G. Gagne, "Identification and characterization of a small molecule AMPK activator that treats key components of type 2 diabetes and the metabolic syndrome", Cell Metab., 3, 403416 (2006).

46- U. Singh, A. Barik, B. G. Singh and K. I. Priyadarsini, "Reactions of reactive oxygen species (ROS) with curcumin analogues: Structure-activity relationship", Free Radic. Res., 45, 317-125 (2010).

47- K. K. Soudamini, M. C. Unnikrishnan, K. B. Soni and R. Kuttan, "Inhibition of lipid peroxidation and cholesterol levels in mice by curcumin", Ind. J. Physiol. Pharmacol., 36, 239-243 (1992). 
48- A. Bonnefont-Rousselot, B. Raji, S. Walrand, M. Gardes-Albert, D. Jore and A. Legrand, "An intracellular modulation of free radical production could contribute to the beneficial effects of metformin towards oxidative stress", Metab., 52, 5869 (2003).

49- N. Ouslimani, J. Peynet, D. BonnefontRousselot, P. Therond, A. Legrand and J. L. Beaudeux, "Metformin decreases intracellular production of reactive oxygen species in aortic endothelial cells", ibid., 54, 829-834 (2005).

50- I. Lin and A. Chen, "Curcumin diminishes the impacts of hyperglycemia on the activation of hepatic stellate cells by suppressing membrane translocation and gene expression of glucose transporter-2", Mol. Cell Endocrinol., 333, 160-171 (2011).

51- G. M. Raso, E. Esposito, A. Iacono, M. Pacilio, S. Cuzzocrea, R. B. Canani, A. Calignano and R. Meli, "Comparative therapeutic effects of metformin and vitamin $\mathrm{E}$ in a model of non-alcoholic steatohepatitis in the young rat", Eur. $\boldsymbol{J}$. Pharmacol., 604, 125-131 (2009).
52- P. Usharani, A. Mateen, M. Naidu, Y. Raju and N. Chandra, "Effect of NCB-02, Atorvastatin and placebo on endothelial function, oxidative stress and inflammatory markers in patients with $\mathrm{T} 2$ diabetes mellitus: A randomized, parallelgroup, placebo-controlled, 8-week study", Drug in $\boldsymbol{R} \& \boldsymbol{D}, 9,243-250$ (2008).

53- A. Gómez-García, G. M. Torres, L. E. Ortega-Pierres, E. Rodríguez-Ayala and C. Álvarez-Aguilar, "Rosuvastatin and metformin decrease inflammation and oxidative stress in patients with hypertension and dyslipidemia", Rev. Esp. Cardiol., 60, 1242-1249 (2007).

54- B. B. Aggarwal and B. Sung, "Pharmacological basis for the role of curcumin in chronic diseases: An age-old spice with modern targets", Trends Pharmacol. Sci., 30, 85-94 (2009).

55- A. E. Caballero, A. Delgado, C. A. Aguilar-Salinas, A. H. Naranjo, J. L. Castillo and T. Cabrera, "The differential effects of metformin on markers of endothelial activation and inflammation in subjects with impaired glucose tolerance: A placebo-controlled randomized clinical trial", J. Clin. Endocrinol. Metab., 89, 3943-3948 (2004). 


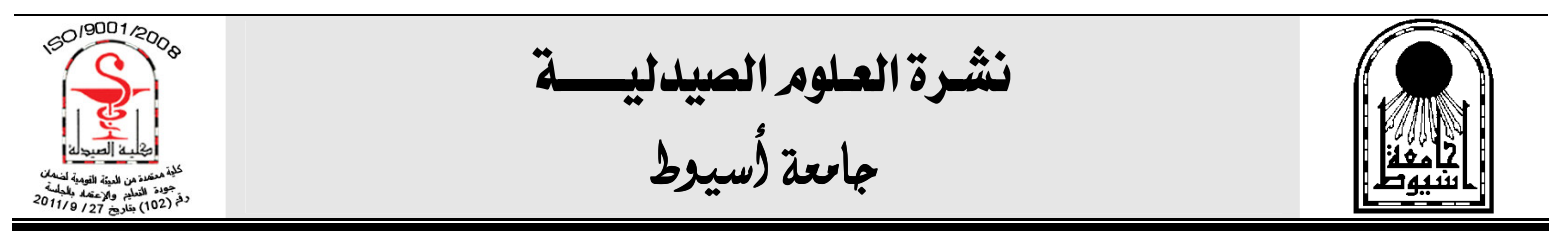

\section{تقييم التأثير الوقائي المحتمل للكركيومين مقارنة بالميتفورمين في المتلازمة الأيضية المستحدثة تجريبيا في الجرذان بانئن}

عبد الحليم محمد عفيفي - حسين اسماعيل البيطار - مروي عبد الرحيم أحمد قسم الفارماكولوجي ، كلية الطب ، جامعة أسيوط ، أسيوط 7 Y Y Y ، مصر

أجريت هذه الدر اسة بغرض تقييم التأثير الوقائي للكركيومين (المادة الفعالة في نبات الكركم) ومقارنتها بالميتفورمين (الثائع استخدامه في علاج مرض السكري) في المنلازمة الأيضية المستحدثة

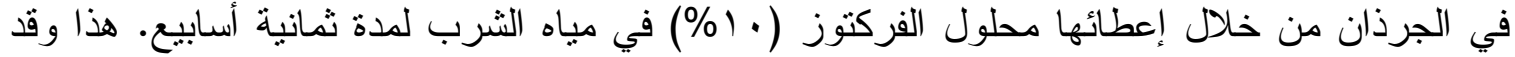

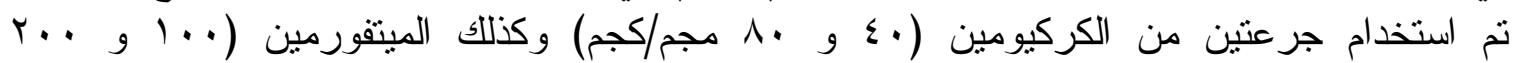

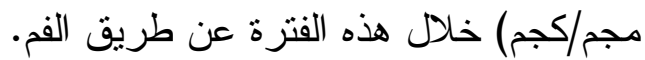

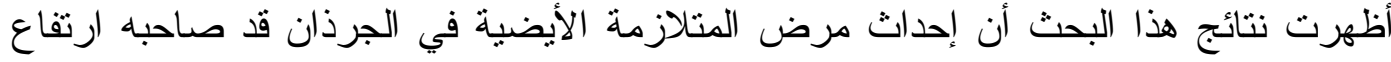
في مستوي السكرو الإنسولين بالاضافة إلي دلالات مقاومة الإنسولين مع انخفاض ملحوظ في مستوي

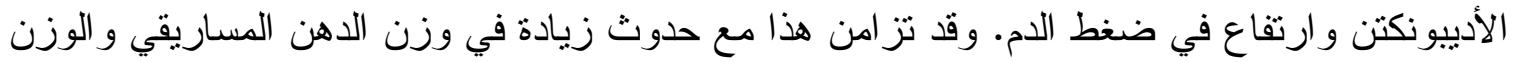

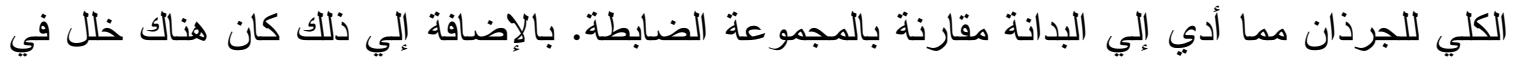
كل من مستويات الدهون بالام (الدهون الثثلاثية ، الكوليستيرول الكلي و البرونينات الدهنية الدهاتية عالية الكثافة

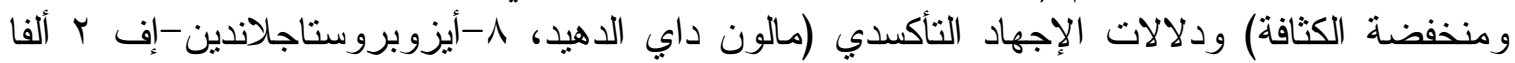

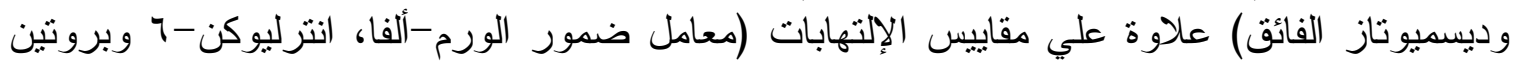

وقد أوضحت النتائج فاعلية كلا من الكركيومين و الميتفورمين في منع تطور معظم علامات سي المتفاعل).

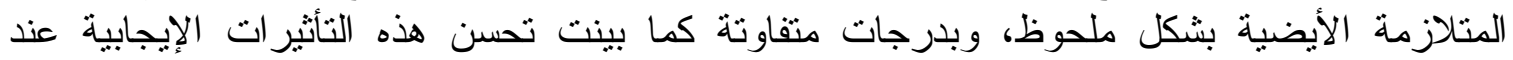

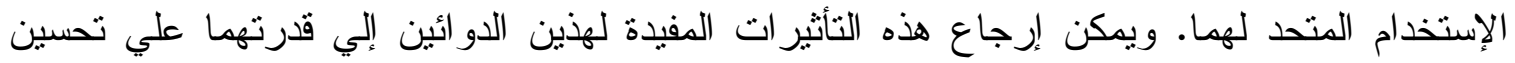
الخلل في الإجهاد التأكسدي و العمليات الإلتهابية المصاحبة لحدوث مرض التهات المتلازمة الأيضية. مع هذا فإننا مازلنا في حاجة إلي الكثير من التجارب للوصول إعلي نتائج أكثر تحديدا. 